\title{
Entrepreneurship Education: A Viable Tool for Youth Empowerment in Nigeria
}

\author{
Lucas .B. Ojo (Ph.D.) \\ School of Technical Education \\ Yaba College of Technology, Yaba, Lagos \\ In affiliation with University of Nigeria, Nsukka \\ E-mail:lucasojobab@yahoo.com, Tel:08023936041,07032668933
}

Alaka Ambali Abayomi (Ph.D.)

The Institute of Chartered Accountants of Nigeria Victoria Island, Lagos, yomibunmi1972@gmail.com

Tel: 08055300996

Odozi, Anuli Faith

Students Affairs Unit(Counselling Department Yaba College of Technology, Yaba, Lagos E-mail:anwuliodozi@yahoo.com Tel:08034183088, 08084300962.

Doi:10.5901/ajis.2014.v3n4p11

\section{Abstract}

This paper examined entrepreneurship education as a veritable tool for youth empowerment in Nigeria. As the nation is presently experiencing challenges of unemployment, insecurity, and high rate of poverty, the study observed that one of the most efficient ways to empower the youth is through entrepreneurship education. The objectives of entrepreneurship education includes but not limited to equipping individual and creates in the person the mindset to undertake the risk of venturing into something new by applying the knowledge and skills acquired in schools. The paper took a critical look at the roles of entrepreneurship education such as provision of individual with adequate training that will enable creativity and innovative relevance to skill acquisition which encourages self employment and self-reliant. It reviewed some techniques of acquiring entrepreneurship skills which includes industrial training exercise, workshop/seminar, excursion and this aid in the empowerments of youth and consequently eradication of poverty and extreme hunger. The paper identified challenges facing entrepreneurship education such as inadequate funding, lack of trained teachers, and non- availability of equipment. The paper recommended that the curriculum at all levels of education should be entrepreneurial based and that all stakeholders and government should provide enabling environment for the development of entrepreneurship education needed for economic enhancement and youth empowerment in Nigeria.

Keywords: Entrepreneurship Education, Skills Acquisitions, Poverty alleviation, Youth Empowerment.

\section{Introduction}

Nigeria, a country with an estimated population of 170 million people (NBS, 2013) is well endowed with abundant human and natural resources and a favorable geographical location in the world map. The current global financial crisis has impacted negatively on the macro and micro levels of the economy of Nigeria. As at present, the situation has poses serious threats and challenges to both government and well meaning citizens. Nigeria like most developing nations of the world is faced with myriad of problems which include youth and graduate unemployment, high rate of poverty, conflict and diseases, insincerity, over-depending in foreign goods, low economic growth and development, lack of capacity and skills needed to move the economy forward and urbanization.

Unemployment has become a major problem bedeviling the lives of Nigerian Youth causing frustration, dejection and depending on family members and friends. The high rate of unemployment among the youths in Nigeria has contributed to the high rate of poverty and insecurity in the country (Ajufo, 2013). More than half of the Nigerian population is under the age of 30 according to the National Population Commission (2013). Awogbenle and Iwuamadi 
(2010) observed from the excepts of statistics obtained from the National Manpower Board and Federal Bureau of statistics that Nigeria has a youth population of eighty (80) Million representing 60 percent of the total population of the country. Sixty four (64) Million of them are unemployed while one million six hundred thousand (1.6 million) are underemployed.

According to Ossal and Nwalado (2012) the need for entrepreneurship education started emerging in the mid 1980s, when there were political instability and inconsistencies in the socio-economic policies of successive government, high level of unemployment, large scale lay off of workers and early retirements as a result of structural adjusted policies and bad economic trends. In the face of these challenges there was no encouragement from the federal government for public and private investors to embark on entrepreneurial activities. These situations pose great challenges to the very existence of individuals and the national development. To salvage these situations there is need for the training of educated man and woman who can function effectively in their society in which they live in terms of self employment and self reliant which only entrepreneurship education can provide. Based upon this premise, the paper examined entrepreneurship education as a veritable tool for youth empowerment in Nigeria.

\section{Review of Related Literature}

\subsection{Conceptualizing Entrepreneurship Education}

Entrepreneurship Education means many things to many people. Nwabuama (2004) view entrepreneurship education as the identification of the general characteristics of entrepreneurs and how potential entrepreneurs can be trained in management techniques needed for effective performance of persons for long time survival of an organization after the acquisition of occupational skills. Olawolu and Kaegon (2012) confirms that entrepreneurship education prepares youths to be responsible and entering individuals who become entrepreneurs or entrepreneurial thinkers by exposing them in real life learning experiences where they will be required to think, take risks, manage circumstances and incidentally learn from the outcome. Ememe (2010) observes that entrepreneurship education enables youths to seek for success in ventures through one's effort.

To Ebele (2008) entrepreneurship education is the teaching of knowledge and a skill that enables the students to plan, start and run their own business. In the view of Swarland (2008), entrepreneurship education aims to stimulate creativity in students, enables them to identify opportunities for innovation and motivate them to transform the ideas into practical and targeted activities whether in a social, cultural or economic context. Amusan (2004) agrees that entrepreneurship education will provide opportunities for students to access their attitude, aptitude and skills relating to those necessary for developing and running business.

Entrepreneurship education entails teaching students, learners and would-be businessmen, the essential skills required to build viable enterprises, equipping the trainees with skills needed for taking responsibility and developing initiatives of prospective trainees (Ezeani, 2012).According to Abefe-Balogun (2012). Entrepreneurship education involve a dynamic process of creating wealth through the process of creating something new and in the process assumes both attendant risks and rewards. Izedonmi (2006) states categorically that it is a process of preparing trainees for selfemployment. Okereke and Okorofor (2011) assert that entrepreneurship education has been acknowledged world wide as a potent and viable tool for self-empowerment, job and wealth creation. To Atakpa (2011) Entrepreneurship education is an aspect of education which equips an individual and create in the person the mindset to undertake the risk of venturing into something new by applying the knowledge and skills acquired in school. Also to Fashua (2006) entrepreneurship education creates the willingness and ability in a person to seek out investment opportunities in the society and be able to establish and run an enterprise successfully based on the identified opportunities. Hence, the overall purpose of entrepreneurship education is to develop expertise as an entrepreneur.

Entrepreneurship education entails philosophy of self-reliance such as creating a new cultural and productive environment promoting new sets of attitudes and culture for the attainment of future challenges (Ogundele, Akingbade and Akinlabi, 2012)

\subsection{Entrepreneurship Education Approaches}

Entrepreneurship Education is the type of education which has the ability to impact on the growth and development of an enterprise through technical and vocational training. Basically, entrepreneurship education has its peculiar learning and teaching approaches. At inception the approach adopted for teaching and learning entrepreneurship education was 
writing of business plan (Hill, 1988). The business plan was viewed as ineffective and insufficient to train potential entrepreneurs who is expected to choose or assumes risks, identifies business opportunity, gather resources, initiatives actions and establishes an organization or enterprise to meet such demand or market opportunity (Anyakolu, 2006).

Honig (2004) identified two other teaching approaches, as simulation and games while Solomon (2007) highlighted for teaching approaches includes, business plans writing, Lecture by well known professionals, case studies and closed supervision of programs other approached include experimental learning, visit of experts etc. Upon the above approaches of teaching and learning entrepreneurship education, the experimental teaching that involves pragmatic approach was adjudged to be the best methods based on the various studies carried out by Solomon and Tarabishy in 1999.

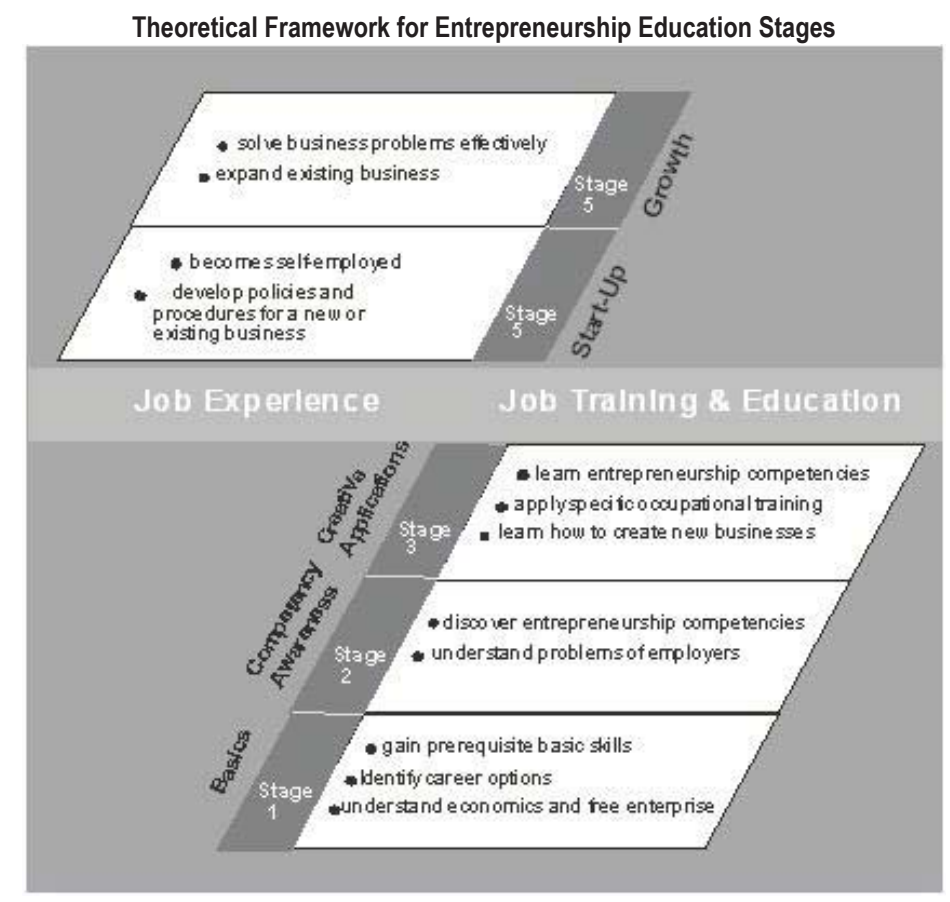

Sources: Isaac E. Visser, K, Iriedrich, C \& Brijla I.P (2007) Entrepreneurship Education and Training in South Africa in South Africa Journal of Education.

The above theoretical framework/model for entrepreneurship education stages implies that there are rooms for entrepreneurship education in our educational systems. Young people can build confidence in their abilities to become entrepreneurs and be empowered in their future as a result of varieties of entrepreneurial activities provided through education.

\subsection{Objectives of Entrepreneurship Education}

Entrepreneurship education according to Paul (2005) in Ossai and Nwalado (2012) is structured to achieve the following objectives

- To offer functional education to the youths that will enable them to be well employed and self-reliant.

- Provide the young graduates adequate training that will enable them to be creative and innovative in identifying novel business opportunities.

- To serve as a catalyst for economic growth and development

- Offer tertiary institution graduates with adequate training in risk management, to make certain learning feasible.

- To reduce high rate of poverty

- Create employment opportunities 
- Reduction in rural-urban migration

- Provide the young graduates with enough training and support that will enable them to establish a career in small and medium sized businesses.

- To incubate the spirit of perseverance in the youths and adults which will enable them to persist in any business venture they embark upon.

- Create smooth transition from traditional to modern industrial economy.

\subsection{Concept of Youth}

Youth is defined by Webster's New Oxford Dictionary in Adebayo (2002) as "the time of life when one is young especially the period between childhood and maturity of the early period of existence, growth or development" the word "youth", "adolescent", "teenager" and "young person's" are often used interchangeably. Youth generally refers to a time of life that is neither childhood nor adulthood but rather somewhere in between. Youth is an alternative word to the scientifically oriented adolescent and the common terms of teen and teenager.

According to Jega (2012) "Youth can be define as a special group of people with strong stamina and passion for realizing certain set goals and objectives ". The way in which a nation defines its youth is related to the objective conditions and realities that exist on the ground especially historical and contemporary socio-economic and political issues that need to be addressed. That is why nations use different parameters and variables in defining their youth. For the purpose of execution of Nigeria's National Youth Development Policy; the youth comprises all young persons of age 18-35 who are citizens of the Federal Republic of Nigeria. This category represents the most culture, the most volatile and yet the most vulnerable segment of the population, socio-economically, emotionally and in other respect. Youth shared certain characteristic that distinguish them from others generation. Such characteristics include, impatient for change, zealousness, radicalism, rebellions, curiosity, hard work, ego and ambition. Looking at the above definition, it is safe to say that, youths are the engine and actualize of national development, if their mindsets are channels in the right direction.

\subsection{The Concept of Youth Empowerment}

According to Ezeanu (2012) sprang from the need to enable young people to have a say in decisions which affect them and to have lower and heard voices. This would give young people the economic, social and cultural advancement of their and countries, and to gain self fulfillment. Young people are empowered when they acknowledge that they have or can create choices in life, are aware of implications of these choices, make an informed decision freely, take action based on that decision and accept responsibility for the consequences of that action.

Youth empowerment is an altitudinal, structural, and cultural process whereby young people gain the ability, authority and agency to make decisions and implement change in their own lives and the lives of other people, including youths and adults (Sasaki, 2006). Empowering youth in this context means creating and supporting the enabling conditions under which young people can act on their own behalf, and on their own terms, rather than at the direction of others. These enabling conditions includes, economic and social base, political will, adequate resources allocation and supportive legal and administrative frameworks, a stable environment of equality, peace and democracy, and access to knowledge, information and skills and a positive value system.

\subsection{The Roles of Entrepreneurship Education}

- Entrepreneurship education can positively impact a learner at all levels on a wide number of contexts. This many explain why there are such a wide entrepreneurship education programs, all of which can provide important outcomes at various stages of a learner's life.

- Entrepreneurship education is a key driver to economy, wealth and a high majority of jobs are created by small business started by entrepreneurially minded individuals. Thus it would make learners to be relevant in today's economy.

- Entrepreneurship education equipped people with traits of creativity, innovation, independence and foresight or promoting local technology. National Directorate of Employment (NDE), Industrial Development Centres (IDC), National Association of Small Scale Industrialists (NASSI), National Association of Small and Medium Scale Employees (NASME), Maintaining Association of Nigeria (MAN) etc provide platform for people to 
appreciate local technology. Training in entrepreneurship has been used by many nations e.g. Germany set up unique engineering oriented business programmes in the University where their potential engineers are encouraged to seek out ideas and subsequently develop the promising ones from invention phase to commercialization. A nation like Norway has also used entrepreneurship education to inculcate innovation spirit, deliberately targeted at the youths. This assertion is in line with the study conducted by Oviare (2010) which state that "entrepreneurship education will enable potential entrepreneurs and create avenues for people to: manage innovation; manage entrepreneurial process, and develop their potentials as managers of creativity in given fields.

- Entrepreneurship activities are a real-life vehicle for developing academic skills. Hence, trained entrepreneurs are always empowered to tap form local resources in their immediate environment. This is a phenomenon that has been demonstrated in China, Japan, India and other emerging economies of the world.

- Entrepreneurship education enables employees to be more successful as a result of understanding the operations of a small business and the problems of their boss

- Entrepreneurship education inculcates in learners the mentality of hard work, one of the keys to unlock poverty doors in developing areas. Entrepreneurs are trained to work hard to be able to run businesses profitably and successfully.

- Youth / Young people can build confidence in their abilities to become entrepreneurs in their future as a result of a variety of entrepreneurial activities provided throughout education.

- Entrepreneurship education provides a guide to empower the youth based on the belief that young people are themselves the best resources for promoting their own development in meeting the challenges and solving the problems faced in today's world and in the new millennium.

- Entrepreneurship education developed good support skills including commenting, decision making, interpersonal abilities, economic understanding, digital skills, marketing, managerial, and financial skills.

- Entrepreneurship education also provide individual with adequate training that will enable creativity and innovative relevance to skill acquisition which encourages self employment and self-reliant

\subsection{Techniques of Acquiring Entrepreneurship Education}

a. Teaching Methods

Fayolle (2009) and Lonappan and Devaraj (2011) classify the teaching methods into following categories: case study, group discussion, individual presentation, individual written report, group project, formal lectures, guest speakers, action learning, seminar, web-based learning and video recorded. Teaching methods are effective in terms of sending the relevant information to a broader population in a relative short time period.

b. Industrial Training Exercise

Skills does not depend solely upon a person's fundamental innate capacities but must be developed through training practice and experience. If the objective of entrepreneurship education is to equip individuals with entrepreneurial skills, which are applicable directly to work, then the best technique is industrial training exercise which would provide education and training that enable individuals to involve directly in the entrepreneurial process.

c. Experimental/Practical Technique

One of the objectives of entrepreneurship educations is to prepare individuals to act as entrepreneurs, one of the most efforts are ways/technique is to facilitate experiments by trying entrepreneurship out in a controlled environment, for instance through business simulation or role playing (Ahmad, Baharun and Rahman, 2004).

d. Excursion Technique

Excursion technique will facilitate first hand information on a particular field of study. This will enable young entrepreneurs' opportunity to acquaint themselves with the various skills needed in accomplishment of their dream and aspirations as future entrepreneurs.

e. Co-operation or Group Learning Technique

This is a process of organizing young entrepreneurs into small groups so that they can work together to maximize their own and each other's learning. Team work is a contemporary form of collaboration. This technique will prompts a sense of mutual responsibility among the entrepreneurs boost their self-esteem, improved social skills and offers greater comprehension of the subject matters. 


\subsection{Entrepreneurship Education Programmes}

It is worthy of note that numerous entrepreneurship programmes have been introduced in many of our institutions either as part of the course of study in Business Administration and Management or as options under the various technical subjects. Often such programmes equate entrepreneurship with new venture creation or/and small business management education "about" entrepreneurship and enterprise rather than educating "for" entrepreneurship. Only rarely, the focus is on developing skills, attributes and behavior of the successful entrepreneur.

There are three types of entrepreneurship programme, namely:

1. Entrepreneurship orientation and awareness programmes which focus on general information about entrepreneurship and encourage participants to think in terms of entrepreneurship as a career.

2. New enterprise creation programmes designed to develop competences, which lead to self employment, economic self-sufficiency or employment generation and

3. Programmes with a focus on small business survival and growth: The emphasis in these programmes is on learning about entrepreneurship and how to manage a small business.

\subsection{Rationale for Youth Empowerment in Nigeria}

The empowerment of young people in Nigeria as at today should be everybody's business, which includes the government, inter-governmental and non-governmental organization, private sectors, family and even the community. It is no longer news today that most people involved in criminal activities fall in the youth age bracket. The Niger Delta in particular which produces over 90 percent of the Nation's oil has been plagued with series of kidnapping by militants. Armed robbery is on the increase due to unemployment, irregular power supply, volatile Nigerians political landscape and above all corruption, all these are negatively affecting the development of the country and even keeping Nigeria as one of the World's poorest countries.

The issue of unemployment has become a global issue. In the USA for instance unemployment had increased from 5 percent in 2007 to 9 percent in 2011. That of Spain has risen from 8.6 percent to 21.53 percent as a result of the debt crisis in Europe. In the UK from 5.3 to 8.1 percent while that of the Greece rose from 8.07 to 18.4 percent during the same period (Salami, 2013). The average unemployment rate within the African continent is generally high, South Africa have 25 percent unemployment rate, Botswana at 17.5 percent, Angola at 25 percent and Kenya at 11.7 percent (Allawadi, 2010)

Fig. 1: Nigeria Unemployment Rate Percentage of the Labour force

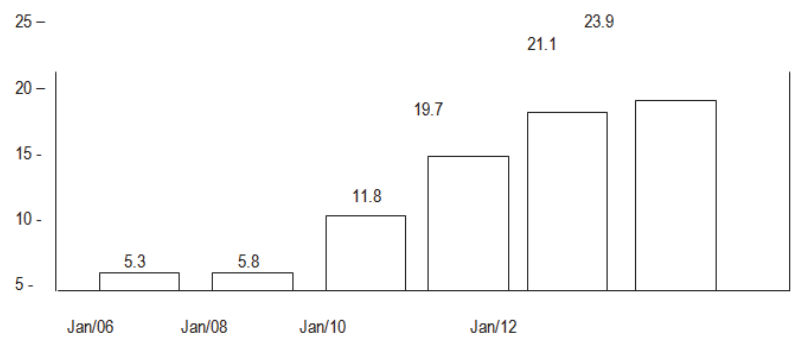

Source: www.tradingconwocs.com 1 National Bureau of Statistics 2012

On the issue of unemployment rate in Nigeria, fig 1 clearly shows the overall unemployment rate in Nigeria which has increased to 23.9 percent in 2012 compare to $21.1 \%$ percent in 2011 and 19.7 percent in 2010 respectively. Based on the unemployment ratio of 23.9 percent of the total population, it means that over 38 million Nigerians are presently unemployed of the total workforce; it means that 1.6 million are unemployed. If the young people are not provided with employment opportunities, there is a chance that they risk becoming disaffected and also turn to crime and violence in order to survive or be co-opted by extremist groups to engage in terrorist acts. Ojo (2013) attributed the youth unemployment problems to four major factors (i) high population growth it is estimated that there are approximately 6 million addition to the population every year, and 1.8 million new entrants to the labour market annually, (ii) low literacy 
rates - Nigeria has low education outcomes with high dropout rates (iii) a poor investment climate; and (iv) a lack of targeted investment in key, youth-dominated sectors.

Table1: Unemployment rates by state $2007-2011$

\begin{tabular}{|c|c|c|c|c|c|}
\hline State & 2007 & 2008 & 2009 & 2010 & 2011 \\
\hline Abia & 25.1 & 11.9 & 14.5 & 22.8 & 11.2 \\
\hline Adamawa & 21.5 & 13.5 & 29.4 & 24.6 & 33.8 \\
\hline Akwa-ibom & 18.0 & 11.1 & 34.1 & 27.7 & 18.4 \\
\hline Anambra & 14.9 & 7.3 & 16.8 & 10.8 & 12.2 \\
\hline Bauchi & 20.5 & 6.9 & 37.2 & 27 & 41.4 \\
\hline Bayelsa & 21.9 & 67.4 & 41.5 & 27.4 & 23.9 \\
\hline Benue & 7.9 & 7.8 & 8.5 & 6 & 14.2 \\
\hline Borno & 12.5 & 11.8 & 27.7 & 26.7 & 21.1 \\
\hline Cross-River & 32.8 & 18.9 & 14.3 & 27.9 & 18.2 \\
\hline Delta & 22.9 & 11.5 & 18.4 & 29.9 & 27.2 \\
\hline Ebonyi & 7.9 & 5.1 & 12 & 25,1 & 23.1 \\
\hline Edo & 14.8 & 15.6 & 12.2 & 27.9 & 35.2 \\
\hline Ekiti & 11.4 & 11.5 & 20.6 & 28 & 12.1 \\
\hline Enugu & 14.1 & 10.5 & 14.9 & 28 & 25.2 \\
\hline Gombe & 16.9 & 7.6 & 32.1 & 27.2 & 38.7 \\
\hline Imo & 28.3 & 17.4 & 20.8 & 28.1 & 26.1 \\
\hline Jigawa & 27.0 & 5.9 & 26.5 & 14.3 & 35,9 \\
\hline Kaduna & 8.7 & 12.7 & 11.6 & 12.4 & 30.3 \\
\hline Kano & 10.1 & 5.8 & 27.6 & 14.7 & 21.3 \\
\hline Katsina & 10.9 & 11.8 & 37.3 & 11 & 28.1 \\
\hline Kebbi & 1.3 & 16.5 & 12 & 10.7 & 25.3 \\
\hline Kogi & 14.6 & 16.4 & 19 & 9.5 & 14.4 \\
\hline Kwara & 17.7 & 10.2 & 11 & 2.7 & 7.1 \\
\hline Lagos & 13.7 & 7.6 & 19.5 & 27.6 & 8.3 \\
\hline Nassarawa & 11.8 & 17 & 10.1 & 3.4 & 36.5 \\
\hline Niger & 4.2 & 3.9 & 28 & 11.7 & 39.4 \\
\hline Ogun & 3.6 & 5.8 & 8.5 & 27.8 & 22.9 \\
\hline Ondo & 6.7 & 6,3 & 14,9 & 28 & 12,5 \\
\hline Osun & 7,2 & 6,5 & 12,6 & 27,6 & 3 \\
\hline Oyo & 8.1 & 8.7 & 14.9 & 27.7 & 8.9 \\
\hline Plateau & 6.8 & 4.7 & 7.1 & 10.4 & 25.3 \\
\hline Rivers & 66.4 & 12.1 & 27.9 & 27.8 & 25.5 \\
\hline Sokoto & 12.3 & 5.9 & 22.4 & 15.9 & 17.9 \\
\hline Taraba & 15.2 & 19.9 & 26.8 & 24.7 & 12.7 \\
\hline Yobe & 24.4 & 12.8 & 27.3 & 26.2 & 35.6 \\
\hline Zamfara & 19.1 & 16.4 & 13.3 & 14.5 & 42.6 \\
\hline FCT & 47.8 & 8.7 & 21.5 & 11.8 & 21.1 \\
\hline Nigeria & 12.7 & 14.9 & 19.7 & 21.4 & 23.9 \\
\hline
\end{tabular}

Sources: General Household Survey Report/NBS/CBN Surveys.

\section{Challenges Facing Entrepreneurship Education and Youth Empowerment in Nigeria}

Entrepreneurship Education has been receiving increasing recognition as a source of job creation, empowerment for the unemployed and economic dynamism in a rapidly globalizing world. But despite this, there are several factors that hinder entrepreneurship education in Nigeria they include:

1. Poor knowledge based economy and low spirit of competition

2. Poor enterprising culture

3. Lack of entrepreneurship teachers, materials and equipment

4. Unavailability of fund

5. Non-inclusion of entrepreneurship programme in the school curricula 
6. Poor societal attitude to Technical and Vocational Education development.

7. Inadequate facilities and equipment for teaching and learning.

8. Insensitivity of government to enterprise creation and expansion strategy.

9. Poor plan and execution of processes of action.

10. Isolated or pockets of ineffective programmes and management in competencies (Oviawe and Ekhovbiye, 2008).

In the same vein, the National Youth Policy (2001) highlighted some of the challenges facing youth and the National Development.

- Inadequate parental care

- Non-availability of suitable sports and recreational facilities

- Moral decadence in the society

- Lack of appropriate role models

- Religious fanatism

- Cult activities

- Political manipulation of youth organizations

- Poor education

- Break down of family values, and

- Indiscipline

Despite the difficult situation and the dire need for change, the government has done little to reduce the misery and frustrations of its citizens, fostering hopelessness in the majority of young people who have resorted to any means, including crime to succeeded in life. The youths are expected not to involve in crime but to channel their strength towards the development of our dear country, Nigeria.

\section{Strategies for Effective Entrepreneurship Education and Youth Empowerment in Nigeria}

Young people are the future leaders of tomorrow. Hence, this fact should be at the core of pro-youth policies and programs, both in the public and private sectors. Ayodele (2006) suggested the following strategies that will help to solve the problem of entrepreneurship education and youth empowerment in Nigeria.

1. Government should establish small business schools where interested students and community members can participate. This will make students to be self reliant.

2. Government should develop entrepreneur internship programme by matching students with locally successful entrepreneurs with clearly stated education programmes.

3. The government should establish an enterprise college aimed at fostering the specific skills required for entrepreneurship. This will serve as skill-acquisition centre for the youths.

4. Government should create an economic friendly environment. This center on reduction of taxes on small scale businesses.

5. There should be enough incentives for students of vocational and technical schools. This will motivate them to establish their businesses after school.

6. There should be some form of genuine school work based learning incorporated in some studies as part of the national economic development strategies. This implies enriching the curriculum to incorporate more vocational and technical training. The development of apprenticeship scheme would give new graduates some work skills and experiences.

7. There should be school-based enterprises where students identify potential business, plan, create and operate small business by using the school as mini-incubators.

\section{Conclusion}

Entrepreneurship Education has been viewed in this paper as a veritable antidote to the endemic problem of poverty, hunger and youth employment. When youth are trained, they explore opportunities in their immediate rural environment instead of chasing shadows and uncertainties in the urban centres. The development of entrepreneurship education will go a long way in creating employment, give young people the opportunity to develop their enterprising skills, empowering the young to be job creators and not job seekers and by providing them with the necessary skills and knowledge to raise their output; income and wealth. Entrepreneurship education would also contribute to improve the image and highlight the 
role of entrepreneurs in society.

\section{Recommendations}

The wheel of development of any country lies on the shoulders of how productive and creative the youths are. The government, parents and guardians have obligations to ensure that youth are empowered to discharge their obligations to the society and to better their life. In the light of the issues discussed above, the following recommendations are proffered.

- Finding of entrepreneurship education should be taken seriously by the federal government. This can be achieved through increase in the budgetary allocation to educational sector.

- Entrepreneurship education should be inculcated into the school's curriculum to promote human empowerment and development through entrepreneurial skill acquisition. It is a means of reducing unemployment since it is skilled oriented and employment motivated. All school programmes should be geared toward providing entrepreneurial skills.

- The private partners and Non-Governmental Organization (NGO) should be encouraged to participate in entrepreneurship education through funding or contributions in kind. This involvement should be seen by firms as a long term investment, and as an aspect of their corporate social responsibility to the nation.

- To empower youth, federal government should provide enabling environment and all the necessary equipment and materials for easy teaching and learning entrepreneurship education needed for economic enhancement and youth empowerment in Nigeria.

- The youth should shun joblessness and criminality through the cultivation of entrepreneurial spirit and acquisition of relevant skills that will launch them into enterprise greatness and economic independence.

\section{References}

Adebayo, F.A. (2012). University Education and Poverty Alleviation as Mechanisms for enhancing youth development in Nigeria. International Journal of Psychology and Counselling 4 (1) pp 1-5 January.

Abefe - Balogun, and Nwankpa, N.N (2012). Tackling Unemployment through Vocational Education. Science Education Development Institute, 2(3) 103-110 March.

Ahmad, S.F, Baharam, R \& Rahman, S.H.A (2004). Interest in Entrepreneurship: An exploratory study on engineering and technical students in entrepreneurship education and choosing entrepreneurship as a cancer, in project report. Faculty of Management and Human Resource Development, Skudai, Johor (Unpublished) University, Teknologi Malaysia Institutional Repository (online) Available: http://:eprints.utn.my/2668/.

Ajuto, B.I (2013). Challenges of Youth Unemployment in Nigeria: Effective Career Guidance as a Panacea. African Research Review. An International Multi- disciplinary Journal. Ethiopia 7 (1) 28; pp. 307-321. Jan.

Allawadi, S.C (2010). Entrepreneurship Challenges in 21 st Century. Indian Institute of Materials Management Mumbai.

Amusan, A.O (2004). Inclusion Entrepreneurship into Secondary School Curriculum. Journal Business Administration Management (JOMAM) 51 (1): Ede Federal Polytechnics.

Anyakoha, I.L (2006). Practical tips for Economic Empowerment and Survival, Nsukka: AD Express.

Atakpa, R. A. (2011). Entrepreneurship Education: A sine Qua-non in Business Education in Nigeria. Business Education Journal 1 (11), 1-6.

Awogbenle, A.C Iwuamadi, K.C (2010). Youth Empowerment: Entrepreneurship Development Programme as an intervention Mechanism. African Journal of Business Management 4 (6) 831-835.

Ayodele, J.B (2006). Obstacle to Entrepreneurship Development in Nigeria. In Omotosho, T.K.O Awko, O.I, Wala-Awe \& G. Adaramola (Eds). Introduction to Entrepreneurship Development in Nigeria, Aso-Ekiti, UNAD Press.

Ebele, O.P (2008). Introduction of Entrepreneurship Education in Business Education Curriculum at University Level in Nigeria. International Journal of Ghana.3 () 1, 30

Ememe, O. N (2011). Entrepreneurship Education in the University in the Eastern Nigeria; Implications for Higher Education Administration Unpublished PhD dissertation, University of Port-Harcourt.

Ezeani, N.S (2012). The Teacher and Skills Acquisitions at Business Education:From the perspective of Accuracy skills: Arabian Journal of Business and Management Remo (OMAH Chapter) 2 (4) Nov.

Fashua, K.O (2006). Entrepreneurship Theory: Strategies and Prentice, Abuja Bee.

Fayolle, A. (2009). Entrepreneurship Education in Europe: Trends and Challenges, OECD, LEED Programme, Universities, Innovation and Entrepreneurship: good prentice workshop. (online) Available: http://www.oecd.org/dataoecd/11/36/43202553.

Hill, G. (1988). Variations in University Entrepreneurship Education: An Empirical Study of an evolving field. Journal of Business Venturing 3, 109-122.

Honig, B. (2004). A Contingency Model of Business Planning, Academic of Management Learning and Education 3 (3) 258-273. 
Isaac, E Visser K, Friendrich, C. and Brij lal ,P .(2007). Entrepreneurship Education and Training in South Africa, in South Africa. Journal of Education. 4(3),33-40

Izodonmi, F. (2008). Entrepreneurship and Wealth Creation the Nigerian Accountant. April/June.

Jega, B.M.B (2012). Nigeria Youth and National Development. Sahara Reporters. March 26, 28-59.

Lonappani, J \& Devaraj, K. (2011). Pedagogical Innovations in Teaching Entrepreneurship in English. AlMS International Conference on Management. Pp. 513-517.

Ogundele, O.J.K, Akingade, W.A and Akinlabi, H.B.(2012). Entrepreneurship Training and Education as Strategic Tools for Poverty Alleviation in Nigeria. American International Journal of Contemporary Research, vol 2, 1, January.

Okereke, L.C and Okorofor, S.N (2011). Entrepreneurship Skills Development for Millennium Development Goals (MDGS) in Business Education. Business Education Journal, 1 (11), 83-88.

Ojo, L.B. (2013). Foundation of Education. A Modern Approach. Bluesign Publication Ltd, Palmgrove, Lagos.

Olawolu, O.E and Kaegon, L.E.S .(2012). Entrepreneurship Education as Tool for Youth Empowerment through Higher Education for global workplace in Rivers. A paper presented at the Seventh Regional Conference on Higher Education for a Globalized World. Organized by the Higher Education Research and Policy Network (HERPNET): holding at the University of Ibadan, Ibadan Nigeria between the $19^{\text {th }}$ to $21^{\text {st }}$ Sept., 2012.

Omoh, G. (2012). Unemployment: A Tickling Time Bomb. Vanguard 25, (61557): p. 19.

Ossal, A.G and Nwalado, E.N (2012). Entrepreneurship Education: A Panacea for Sustainable Development in Nigeria. Journal of Resourcefulness and Distinction 1 (1) April.

Oviame, J.B (2010). Repositioning Nigerian Youths for Economic Empowerment through Entrepreneurship Education. European Journal of Educational Studies. 2 (2).

National Bureau of Statistics (NBS, 2013). Poverty index in Nigeria.

Nwabuana, E.C (2004). Information Technology (IT) and Enhancement of Entrepreneurship Education in Secretarial Studies Programme in Polytechnics in Nigeria. A Paper Presented at the Association of Business Educators UNICA Calabar $2^{\text {nd }}-6^{\text {th }}$ November.

Nwangwu, I.G.O (2007). Entrepreneurship in Education: Concepts and Constraint. African Journal of Education and Development Studies 4 (1), 196-207.

Salami, C.G.E (2013). Youth Unemployment in Nigeria: A time for creative intervention. International Journal of Business and Marketing Management. 1(2) pp. 18-26 July.

Sasaki, S. (2006). Promoting Youth employment through Entrepreneurship Education. http://www.110.org/public/english/ religion/asro/beljing/dowload/speech/asl 18 May 06.pdf. Retrieved on 03 October, 2013.

Solomon, G. (2009). An Examination of Entrepreneurship Education in United State. Journal of Small Business and Enterprise Development. 14 (2). Pp. 168-182.

Swartkabd, J.R (2009). A Study of Entrepreneurship Education in Botswana and the significance of Institutional Preparation (online) www.ADEAnet. Retrieved on 03 Oct. 2013. 